\title{
アフリカ特にゼネガル，マリー両共和国における 最近のハンセン氏病の実態
}

\author{
國越宇市 \\ (栗生楽泉園)
}

\begin{abstract}
緒 言
今からおよそ 700 年程前1)，La Lépre がイギリス， アイルランドおよび東地中海の近隣地方に流行して いた。Les Pirates l'Europe (Vikings) と十字軍達 ${ }^{2)}$ がそれぞれ遠征の地方より本病を持ち帰つたので Bergen 市とその付近は, La Lépre の温床となり, 本病 患者を収容するため St. J $\phi$ rgen Hôpital が初めて設

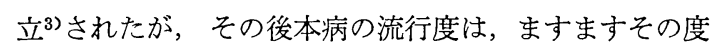
合を加へ, Bergen 市は, 実にその人口50名に対し 1 名 の割合という激しい流行地となつてしまつた。

そこで 2 カ所の Léproseries が 1838年建設されるこ とが決定された。かくて事態は, まさに危機に頻するに 至つた。一方本病患者達を統合したり, 食・住を給与し また入院療法するために病院を設営するなどといらこと と比較すると, もつと重大な思いがけない事件が起りつ つあつたのである。すなわち Dr. Daniel Cornelius")
\end{abstract} Danielssen (1815 1894) が同年彼の畢生の La Lépre に関する学説（本病遣伝説）を発表したからである。 また一方1841年 7 月29日5), Gerhard Henrik Armauer Hansen (1841 1912) は La Norvège の素朴な一家庭 に誰知る人もなく呱々の声をあげていたのである。この ことが旧時代の学説に終止符を打ち, 新時代を画する基 となつた。彼は, のちに La Lépre とその親類達の発 病に関する疑問点に熱情的に取組み, 困難な不屈の病理 学的観察を続行し遂に Mycobacterium leprae を発見 するに至つたのは，皮肉にも反対派の Dr. Danielssen

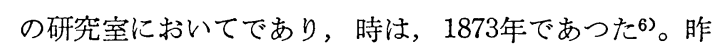
年 8 月 Mycobacterium leprae 発見百年祭を記念して 第10回国際らい学会が彼の生誕地 Bergen 市において 開催された。筆者は, 日本国厚生省より出張派遣を命ぜ られ同学会に出席する好機に接した。同学会中, アフリ 力 Mali 国元らい研究所長 Dr. J. Languillon? に面会 し, l’Afrique 特に Sénégal 共和国, 同 Mali 国の本病 の実態の概略を聞き得たのでアフリカ特に両国の本病の
実情を論じ筆者の考えを併せて論じ度いのが本報告の主 旨である。

\section{アフリカ特に Senegal 共和国両 Mali 国にお ける H 氏病}

アフリカ西海岸だけでも約 450,000 名の 本病患者が在 住している。

Sénégal 国は, アフリカ西北部位置し, 北緯 $12^{\circ} \sim 17^{\circ}$ に存在し, 西部は, 大西洋に面している。昔は, フラ ンスの植民地であつたが，現在では，独立して共和制 を保持しているが今もなおフランスとの絆の絶ち難い状 態にある。首都 Dakar に l'Institut de Lèprologie Appliquée があり本病に関する知識の 普及教育並びに 一般住民達の保健業務を行つている。所長は，仏人 Dr. Languillon である。同博士は，東隣国すなわち Mali 共和国の l'Institut Marchoux de Bamako の元研究 所長であり, 永年本病に関する研究とその治療に専念し て来た仏国政府派遣のベテラン学者である。現在は, 彼 の後継者 Le Médecin Colonel Saint-André にその席 を譲り Senégal の研究所長の職務に従事している。

本国には，本病患者達が実際約 40,000 名（人口比 1.5 \%) 在住している。本病療養所は，6力所に夫々一つづ つあるが， 6 療養所で 2,000 名の患者しか收容していな い。入所患者の病型は, 次の通である。

LL 型 : $5 \%$, TT 型 : $90 \%$, I 群 : $4 \%$, BL 群 : $1 \%$, 入所者以外の患者達に対しては巡回診療を行いま た数力所の無料診療所で治療が行われている。人手不足 のため薬品メーカーが治らい剤を at randam に配給し ている状態である。

\section{治療内容}

原則的には，Disulon $600 \mathrm{mg}$ を曜日を決めて週一 回経口投与する。この方式を繰返す。病状に応じ $\tau$ Sulfamides (Sultirène, Fanasil), Antibiotiques (Rifadine, Trécator, Trévintix, Lampréne)を一日一 
回投与し生検でH氏菌が陰性になるまで永年上述の方式 を繰返す。

Mali 国は, Sénégal 共和国の東隣国に位置し, やは り昔は，フランスの植民地であつたが独立して共和制を 保持しているがフランスとの関係は，今もなお深く医療 援助を受けている。この国には, l'Institut Marchoux de Bamako があり, 本病の研究と本病患者達の治療 に当つている。所長は, 仏人 Le Médecin Colonel Saint-André である。同氏は Dr. J. Languillon の後 継者である。この国の本病患者数は, 実際105,000名(人 口比 $2 \%$ ）にも達している。療養所は, 一カ所しかなく 4,500名の患者達しか収容されていない状態である。治 療内容は, 大体 Sénégal 国と殆んど同じである。

$$
\text { むすび }
$$

Sénégal, Mali の本病患者数は, 日本のそれと比較 すると著明に多く，しかも治療内容のみならず本病患者 の収容施設等の貧困さに対しフランスのみならず各国が 医療援助をなす可きでなかろらか。人類は，神の前で は，平等であり，健康と幸福を享受すべき権利を有する ものであり，世界に不幸な人が一人でもいる限り世界 は，幸福とはいへないであろう。
われわれ本病を専攻するものは勿論日本国もまた出来 れば外交関係を十分考慮に入れ，人道的見地よりこの人 達に医療援助の手をさしのべるべきものと考える。

擱筆するに当り諸種の情報を率直に提供された Dr. J. Languillon に深謝する。

\section{文献}

1) Browne, G. S. : Lepr. Rev. 44, 2, 55-58 (1973).

2) M $\phi$ ller-Christensen V : Lepra og Dens Historie Medisinsk Arbok 17-18 (1961-1962).

3) Irgens, L. M. : Kort Histrikk Vedr $\phi$ rende Lepra og Lepraforskning i Norge. Nord. Vet Med. 22 Suppl. 2, 23-29 (1970).

4) Danielssen, D. C. et al. : Traité de La Spedalskhed ou Éléphanthiasis Des Grecs, Paris, (1848).

5) Skinsnes, O. K. : Internat. J. Lep. 41, 2, 150 (1973).

6) Hansen, G. H. A. : Undels $\phi$ gelser Angaaende Spedalskhendens Aarsagar. Norsk Mag. f. Laegev. 4 Suppl. 1-88 (1874).

7) Languillon, J. : Communications Personelles, Août (1973). 